УДК 624.131.1.

\title{
ОПОЛЗНЕВАЯ ОПАСНОСТЬ НА ШУФАНСКОМ ПЛАТО ДЛЯ ЛИНЕЙНЫХ ОБЪЕКТОВ ИНФРАСТРУКТУРЫ (ПрИМорсКИЙ Край)
}

\author{
Квашук С. В. ${ }^{1}$, Малеев Д. Ю. ${ }^{1}$, Федоренко Е. В. ${ }^{2}$ \\ 'Дальневосточный государственный университет путей сообщения, г. Хабаровск \\ ${ }^{2} О О О$ «Миаком СПб», г. Санкт-Петербург \\ E-mail: s_kvashuk@mail.ru,mdy@list.ru, evgeniy@miakom.ru
}

\begin{abstract}
Вдоль кромки базальтовых покровов Шуфанского плато широко развиты действующие вязкопластические оползни-потоки. Дана краткая орографическая, тектоническая и геологическая оценка района. Оползни, оврагообразование, денудационные явления нарушают нормальный ритм работы транспортных магистралей. Приводятся результаты исследований условий и причин процесса. Установлено, что главным условием оползания является трассирование этих магистралей по пологим склонам (12-15), сложенным нелитифицированными глинами, а основной причиной - переход глин в пластичное состояние в период затяжных моросящих дождей, характерных для этого района. Проработка вариантов инженерной защиты железнодорожной линии от оползней по периферии Шуфанского плато показала, что применение каждого из них весьма проблематично. При освоении территории необходимо учитывать сейсмотектоническую опасность регионального Нижне-Суйфунского разлома, совпадающего с долиной р. Раздольная, и современные вертикальные движения земной коры в этой зоне.
\end{abstract}

Ключевые слова: Шуфанское плато, геологическое строение, сейсмическая опасность, оползни, индикационные признаки, инженерная защита.

DOI: 10.34078/1814-0998-2021-1-40-49

\section{ВВЕДЕНИЕ}

Территория исследований, результаты которых изложены ниже, расположена в пределах Хасанского и Надеждинского административного районов Приморского края.

Она протянулась довольно узкой полосой между морским заливом и границей Российской Федерации.

Данная территория активно эксплуатируется. Она является стратегическим транспортным коридором из Российской Федерации в страны Азиатско-Тихоокеанского региона по автомобильной и железной дорогам регионального значения с большим объемом перевозимых грузов и пассажиров. Также по этим магистралям осуществляется транзит грузовых потоков к незамерзающим морским портам, расположенным здесь.

Кроме того, указанные административные районы являются курортными для всего Дальневосточного региона. Здесь в летний период отдыхают тысячи дальневосточников, что объяс2021

(C) Квашук С. В., Малеев Д. Ю., Федоренко Е. В., няется мягким климатом и уникальными комфортными пляжными условиями на многочисленных туристических базах и в санаториях.

Геологическое строение территории довольно специфично. Исследования показали, что в соответствии с комплексом условий, охарактеризованным в статье, здесь проявляются оползневые деформации, осложняющие эксплуатацию автомобильной и железнодорожной магистралей и все другие виды освоения территории. Это вызывает необходимость мониторинга ситуации, а также разработки и внедрения мероприятий по стабилизации опасных участков, что приводит к нежелательным значительным дополнительным финансовым затратам.

Цель текущего исследования - анализ условий и причин активизации процессов оползневых деформаций и рекомендации по их стабилизации и устранению.

Проблема устойчивости территорий, подверженных оползневым деформациям, является весьма острой и исследуется специалистами со времен формирования предмета «инженерная геология». Можно назвать имена Ф. П. Саваренского, Е. М. Сергеева, Г. А. Голодковской, В. Д. Ломтадзе, Г. К. Бондарика, М. В. Чуринова, 
А. И. Шеко, Ю. Б. Тржцинского, В. К. Лапердина, А. М. Лехатинова и многих других ученых.

Условия, причины и закономерности развития экзогенных процессов на территории исследований рассмотрены в трудах А. М. Короткого с соавторами (2009), В. С. Рынкова (1976).

Интенсивность оползневых деформаций в связи с оценкой сейсмичности территории Анализировали Н. М. Органова Н. М. (1977) и А. А. Олейникова с Н. А. Олейниковым (2001).

\section{КРАТКАЯ ОРОГРАФИЧЕСКАЯ, ТЕКТОНИЧЕСКАЯ И ГЕОЛОГИЧЕСКАЯ ХАРАКТЕРИСТИКА РАЙОНА}

В орографическом отношении район охватывает восточную часть Восточно-Маньчжурского нагорья и юго-западную часть западного СихотэАлиня. Нагорье «заходит» в пределы России лишь своей восточной частью, занимая территорию между государственной границей и левобережьем низовьев р. Раздольная, на участке ее субмеридионального течения и южнее - побережьем Японского моря. В пределах района нагорье делится по долине р. Амба на две части - Шуфанское плато и Хасанско-Барабашский горный район. Большая часть плато расположена к западу от р. Раздольная и севернее р. Амба, вместе с тем небольшие реликты сильно эродированных периферийных частей плато сохранились и восточнее р. Раздольная, и южнее р. Амба. Таким образом, большая часть района исследований представляет собой юго-восточную часть Шуфанского плато.

Согласно принятому тектоническому районированию досенонских структур, рассматриваемый район относится к пригеосинклинальному прогибу области герцинской (позднепермской) складчатости, обрамляющей Ханкайский срединный массив. На территории района пригеосинклинальный прогиб разделен НижнеСуйфунским разломом на складчатые системы: Лаоелин-Гродековскую и Сихотэ-Алиньскую (Государственная..., 2008).

На территории района позднепермские образования обнажены всего в нескольких местах и представлены сильнодислоцированными вулканогенными, вулканогенно-осадочными и карбонатными породами барабашской свиты и прорывающими их гранитоидами. На большей части площади района палеозоиды с размывом и несогласием перекрыты отложениями триасового, юрского и мелового возраста, выполняющими две разделенные Нижне-Суйфунским разломом впадины, наложенные на герцинский фундамент: Раздольненскую - к западу от разлома и Артемо-Тавричанскую - к востоку от него (Геология СССР, 1974). Мезозойские отложения дислоцированы в меньшей степени по сравнению с палеозойскими, прорваны лишь редкими и небольшими по величине интрузиями позднемеловых диоритов и на большей части площади района перекрыты полого залегающими на них с размывом и угловым несогласием кайнозойскими рыхлыми отложениями и базальтами.

Распространены следующие современные экзогенные процессы и явления:

оползневые процессы, приуроченные к краевым частям Шуфанского плато, где базальты залегают на палеоген-неогеновых глинистых отложениях и прорезаны речной сетью на полную мощность. Развиваются после ливней и продолжительных дождей. Имеют доминирующее влияние при оценке территории;

оврагообразование на рыхлых кайнозойских отложениях вблизи береговых уступов, возникающее в результате нарушений, связанных с деятельностью человека. Процесс интенсивен в периоды ливневых осадков, затухает со вскрытием докайнозойских пород;

распространение карста - ограниченное и приуроченное к верхнепермским известнякам терригенно-карбонатной формации;

интенсивные процессы денудации (рис. 1).

Климат района имеет определяющее значение в интенсивности опасных экзогенных процессов. Он умеренно муссонный, влажный. Здесь суровые и малоснежные зимы, снеговой покров менее 0.2 м сдувается резкими ветрами с повышенных участков. Глубина промерзания составляет около 0.8 м. Температура января $-21^{\circ} \mathrm{C}$, минимальная температура достигает $-35 \ldots-40^{\circ} \mathrm{C}$. Осадки в виде снега составляют $20 \%$ от годовой суммы. Погода зимой морозная, солнечная. В январе-феврале, во время оттепели, температура может подняться до $+8^{\circ} \mathrm{C}$. За период с ноября по март на побережье выпадает более 100 мм осадков. К концу марта устанавливается средняя положительная температура воздуха на большей части района. Летом морские муссоны приносят с собой влагу, поэтому лето сырое, облачное, с туманами и частыми моросящими дождями. Свыше 70\% годовой суммы осадков (до 600 мм) выпадает в июне - августе. Важной особенностью второй половины лета являются тайфуны. Три четверти их проходит в августе сентябре. Обильное выпадение осадков, высокие относительная влажность (80-90\%) и температура воздуха (часто выше $+25^{\circ} \mathrm{C}$ ) характерны для этого периода. Вдоль побережья проходит холодное течение, с чем связаны продолжительные туманы в это время года (Погода и климат Приморского края. https://www.meteonova.ru/klimat/25/ Primorsky\%20Kray/).

Район характеризуется умеренной сейсмической активностью. По картам ОСР-2016 А, В и С 


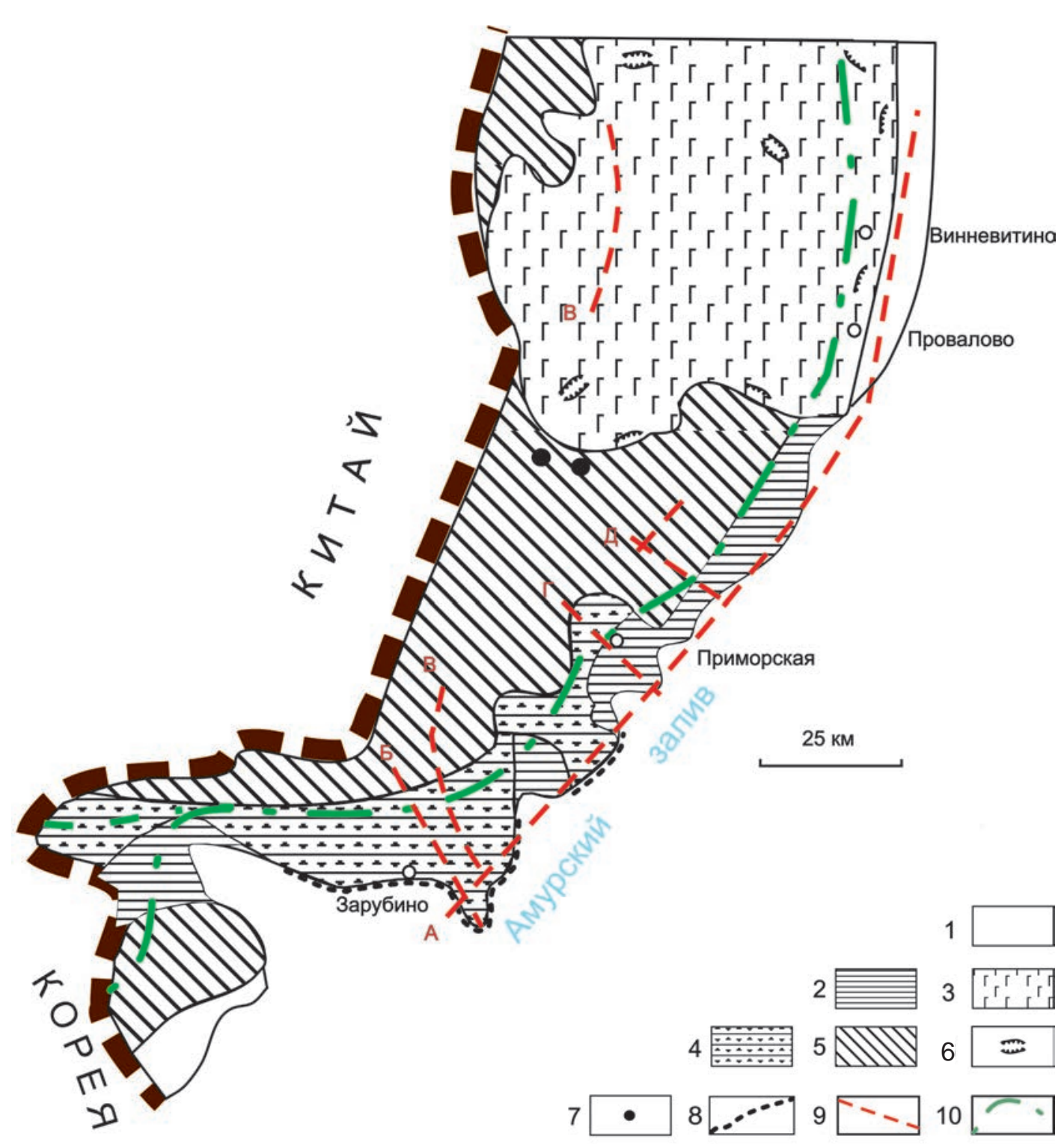

Puc. 1. Схематическая геоморфологическая карта территории в пределах Хасанского и Надеждинского административных районов Приморского края (по И. И. Берсеньеву, В. К. Сохину, Б. П. Пада. Геология СССР, Т. 32), со схемой разломной тектоники (по Н. М. Органовой). Геоморфологические элементы: 1 - современные и позднечетвертичные террасы; 2 - раннечетвертичные террасы; 3 - плиоценовые базальтовые плато (Шуфанское плато); 4 - олигоцен-миоценовые (низкие горы); 5 - раннепалеогеновые террасы, сформировавшиеся преимущественно в результате сводового поднятия Сихотэ-Алиня; геологические процессы: 6 - оползни; 7 карст; 8 - современные абразионные обрывы и овражная эрозия в рыхлых отложениях; тектонические крупные разломы: 9. А - Нижне-Суйфунский (Прибрежно-Раздольненский); Б - Сухановский, В - Адиминский, Г - Кедровский, Д - Барабашевский; 10 - траектории главных объектов транспортной инфраструктуры

Fig. 1. Schematic geomorphological map of the area within the Khasansky and Nadezhdinsky administrative districts of Primorsky Krai (after I. I. Bersenyev, V. K. Sokhin, B. P. Pada. Geology of the USSR, Vol. 32), with the scheme of fault tectonics (after N. M. Organova): Geomorphological elements: 1 - modern and Late Quaternary terraces; 2 -Early Quaternary terraces; 3 - Pliocene basalt plateaus (Shufan Plateau); 4 -Oligocene-Miocene (low mountains); 5 - Early Paleogene terraces, resulted mostly from the Sikhote-Alin arched uplift; Geological processes: 6 - landslides; 7 - karst; 8 - modern abrasion cliffs and ravine erosion in soft deposits; Large tectonic faults: 9. A - Lower-Suyfun (Pribrezhno-Razdolnensky), Б - Sukhanovskyi, B - Adiminsky, Г-Kedrovsky, Д - Barabashevsky; 10 - the routes of main transportation objects

сейсмичность составляет 6,6 и 7 баллов соответственно (по данным населенного пункта Приморский, расположенного в его центральной части) (Комплект..., 2015).
Большинство из зафиксированных за период наблюдения землетрясений глубокофокусные, среди которых имеются события с магнитудой до 7 и более. Коровые землетрясения довольно 
редки и имеют значительно меньший энергетический уровень. Тем не менее они оставили свой след в сейсмической истории района, как, например, Приморское землетрясение 1955 г., которое привело к значительным разрушениям зданий и сооружений в непосредственной близости от ключевых участков (Бормотов, 2004).

\section{ПОСТАНОВКА ПРОБЛЕМЫ}

Совокупность особенностей сейсмических условий, геологического строения территории, в котором участвуют элювиально-делювиальные образования четвертичного возраста, интенсивно меняющие свои физико-механические свойства при увлажнении, и характерный приморский климат, предопределяют активизацию неблагоприятных экзогенных процессов - оползней, карста, оврагообразования и др., что затрудняет освоение территории, строительство и эксплуатацию транспортных магистралей. Задачами исследований были: выяснение масштабов и интенсивности оползневых процессов в районе; разработка конструкций поддержания устойчивости склонов, а также разработка мероприятий по борьбе с оползневыми деформациями.

\section{МЕТОДИКА ИССЛЕДОВАНИЙ}

Участок активных оползневых деформаций был исследован авторами путем проведения инженерно-геологических работ с опробованием пород, геофизических исследований, топогеодезических работ, лабораторных исследований физико-механических свойств осадочных горных пород. Были изучены фондовые и литературные источники. В качестве ключевых представлены участки между станциями Винневи-

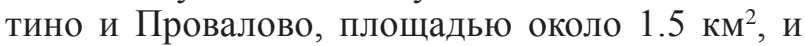
рекогносцировочные маршруты на прилегающей территории.

\section{МАТЕРИАЛЫ ИССЛЕДОВАНИЙ}

Оползневые процессы широко развиты в западной части района, вдоль кромки базальтовых покровов Шуфанского плато, в бортах долин рек, прорезающих базальты ниже их подошвы там, где они залегают на нелитифицированных отложениях. Образуются на склонах гор, сложенных глинами с прослойками рыхлых туфов, туффитов, песков и галечников усть-суйфунской свиты. На участках, где нелитифицированные отложения перекрыты неогеновыми базальтами, обладающими большой водосборной площадью и хорошо фильтрующими подземные воды, оползневые склоны достигают значительных размеров (до 10 км в длину при высоте до 100 м) (Геология СССР, 1974). При этом склоны имеют углы заложения $12-15^{\circ}$.
В пределах исследованного участка наиболее активные оползневые деформации угрожают безопасной эксплуатации транспортных магистралей.

В ходе полевых исследований установлено, что магистрали протрассированы по элювиальноделювиальным образованиям четвертичного возраста, представленным желто-бурыми глинами с хаотическим нагромождением щебня, дресвы, валунов и глыб базальтов размером 0.3-5.0 м в поперечнике, промежутки заполнены щебнем и коричнево-бурыми суглинком. Местами в промежутках между оползневыми буграми наблюдаются выходы подстилающих пород. Иногда оползневые накопления представлены смещенными раздробленными блоками базальтов длиной до десятков метров и высотой до 15 м (мощность 25$30 \mathrm{M})$.

Обломки базальтов трансформированы в зависимости от количества пор: массивные базальты практически не изменены, мелко- и среднепористые лимонитизированы по трещинам, а сильнопористые гематитизированы по массе. Обломки размера дресвы и приповерхностные, внешние части («корочки») более крупных обломков легко растираются в пальцах рук до пыли и являются, таким образом, исходным материалом желтобурых глин.

Тонкодисперсная фракция представлена желто-бурыми влажными тяжелыми пластичными глинами, а у поверхности после дождей - текучепластичными. Мощность элювиально-делювиальных отложений оценивается первыми метрами.

В рельефе базальтовые покровы иногда слабо выражены небольшими положительными формами - водораздельными возвышенностями, иногда асимметричного профиля, с одним крутым и противоположным пологим склоном. Отсутствие коренных выходов базальтов в пределах участка не позволяет достоверно судить о форме и залегании базальтовых тел; можно лишь предполагать, что они представляют собой маломощные ( $\approx 1$ м) пологозалегающие покровы и потоки и/или дайки и некки (тела, выполняющие подводящие каналы).

Ниже желто-бурых глин, а местами непосредственно под почвенно-растительным слоем, по данным бурения, залегают массивные, слаболитифицированные, влажные пластичные глины серо-коричневого цвета с оттенками от кремовосерого (кофейно-молочного) до шоколадного, в зависимости, вероятно, от влажности, так как при высыхании цвет этих глин постепенно меняется от серо-коричневого до светло-серого, а глина становится гигроскопичной, приобретает раковистый излом и становится подобной трепелу. Глины, вскрытые бурением, аналогичны описан- 
ным в коренном залегании в выемках автомобильной трассы.

В выемке автодороги серо-коричневые глины обнажаются в многочисленных узких (шириной 5-10 см) неглубоких (до 10-12 см) промоинах протяженностью до 3 м, прорезающих откос выемки. На этих глинах залегают желто-бурые глины с многочисленными полуокатанными обломками базальтов. Контакт четко выражен в резком перегибе склона с более крутого $\left(\sim 35^{\circ}\right)$ на более пологий $\left(\sim 15^{\circ}\right)$.

Серо-коричневые глины, судя по их залеганию под базальтами, можно отнести к устьсуйфунской свите позднемиоценового возраста, а желто-бурые - либо к нерасчлененным четвертичным покровным отложениям, одевающим почти сплошным чехлом склоны возвышенностей, поверхности и склоны террас (кроме первой надпойменной), либо, как принято нами, к нерасчлененным современным элювиальноделювиальным отложениям.

Проведенные буровые работы показали глубину залегания границы между желто-бурыми и серыми слаболитифицированными глинами - 56 м. Эти данные были подтверждены результатами сейсморазведки методом преломленных волн.

Желто-бурые влажные пластичные тяжелые глины обладают высокой пористостью и при этом слабоводопроницаемы. Через две недели после окончания периода затяжных ливневых дождей (июль) в закопушки и шурфы в течение 2 ч после их проходки инфильтровалась вода, которая стояла в них до наступления периода отрицательных температур.

На местности наблюдается большое количество признаков оползневых деформаций (рис. 2, 3):

земляное полотно автомобильного шоссе испытывает на отдельных участках значительные деформации, что приводит к разрушению асфальтобетонного покрытия;

с верховой стороны железнодорожной насыпи отклоняются вниз по склону старые телеграфные столбы на 29-38 от вертикали;

с низовой стороны железнодорожной насыпи отклоняются вниз по склону старые телеграфные столбы на $2-7^{\circ}$ от вертикали;

ось железнодорожного пути на мостах смещена относительно осей мостов, имеющих значительное заглубление, на 115-320 мм из-за сдвижки оси подходной насыпи вследствие оползневых деформаций. Это обстоятельство существенно усложняет работу пролетных строений и устоев мостов, что может привести даже к аварийным ситуациям;

отсутствие водоотводной канавы с верховой стороны насыпи вследствие наступления языка оползня;

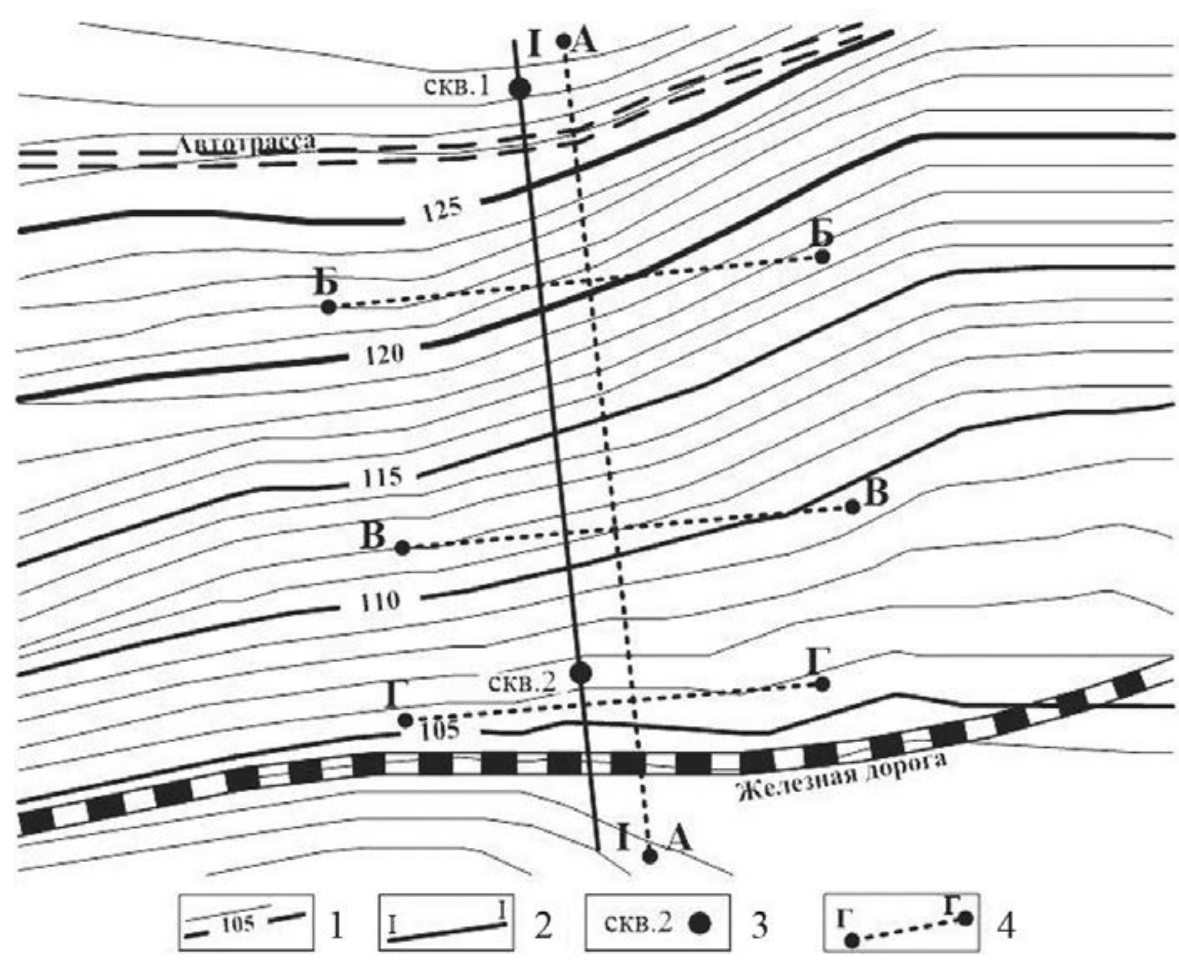

Puc. 2. Схематический план ключевого оползневого участка: 1 - горизонтали рельефа; 2 - линия поперечного разреза; 3 - буровые скважины, 4 - геофизические профили

Fig. 2. Schematic plan of the key landslide site: 1 - topography contour lines; 2 - cross-section line; 3 - boreholes; 4 - geophysical profiles 


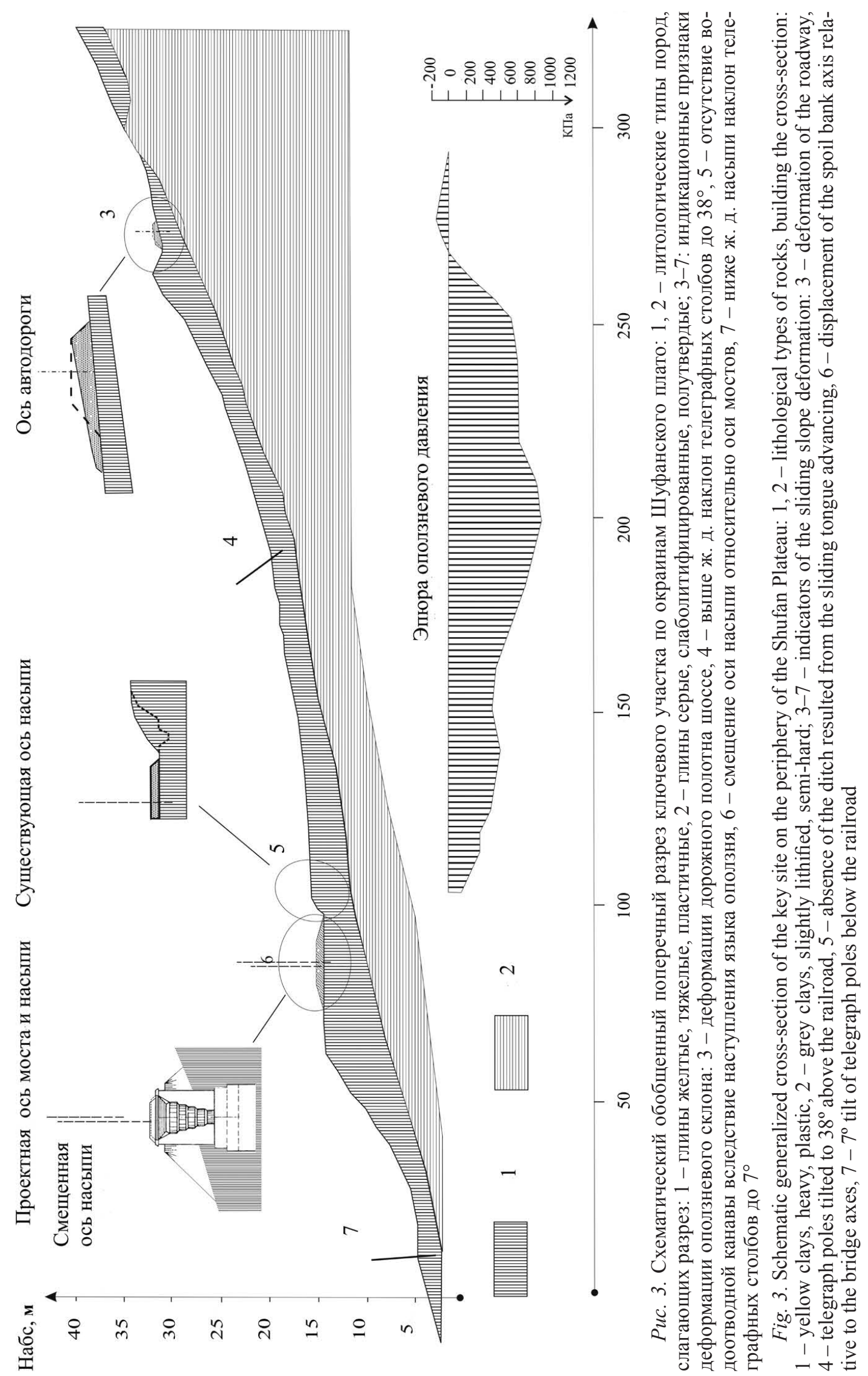


на оползневом склоне произрастают редкие дубы, однако отсутствует индикационный признак - «пьяный лес».

Были проведены аналитические исследования устойчивости склонов по стандартным методикам. Эпюра оползневого давления представлена на рис. 3. Результирующее оползневое давление в различных сечениях колеблется в интервале $132-1100 \mathrm{\kappa H} / \mathrm{M}$.

\section{ОБСУЖДЕНИЕ РЕЗУЛЬТАТОВ}

Обобщая изложенное, можно сделать выводы о том, что для Шуфанского плато характерно проявление действующих вязкопластических оползней. Они активизируются в периоды затяжных дождей, которые типичны для морского климата Приморского края.

Оползни происходят в пределах участков развития элювиально-делювиальных отложений, на склонах с углами заложения до $12-15^{\circ}$, с разной скоростью. Скорость наибольшая - на более крутых участках откосов, с большими гипсометрическими уровнями, снижается на более пологих участках откосов в языковой части оползневого склона, с меньшими высотными отметками.

Очевидно, что нижняя граница оползающего слоя находится ниже, чем глубина развития корневой системы дуба, составляющая около 1.5 м, поскольку явления «пьяного леса» не наблюдается.

Анализ вариантов инженерной защиты железнодорожной линии от оползней по периферии Шуфанского плато показал, что применение каждого из них весьма проблематично.

Использование подпорных стен невозможно из-за отсутствия прочных коренных пород на расчетной глубине. Были проанализированы типовые противооползневые конструкции - свайные подпорные стены, устраиваемые вдоль железной дороги. Расчеты показали, что это могут быть сваи $40 \times 40$ см в сечении, длиной 14.0 м, с шагом 2.5 м в два ряда в шахматном порядке или буронабивные сваи диаметром 0.75 м, длиной 16.0 м, с шагом 3.0-5.0 м. Однако для обоих вариантов необходимо применение тяжелой (до 12 т) техники, со значительными динамическими нагрузками на склон. Это, в свою очередь, может привести к активизации оползневых процессов и к аварийным ситуациям на транспортных магистралях (Маций, Деревенец, 2007).

Наиболее рационально в данных инженерногеологических условиях применение комбинированных решений из геосинтетических интегральных георешеток разной конфигурации и пригрузочных берм из грунта различной ширины, в зависимости от высоты насыпи (нагрузки на основание) и мощности слабых грунтов в основании. Эти выводы были сделаны на основе предварительного геотехнического моделирования работы конструкций.

В сооружениях с высотой насыпи до 6.0 м и мощностью слабого грунта до 15.0 м в качестве несущей рекомендуется объемная конструкция из одноосной интегральной георешетки, собранная в виде сотовых треугольных ячеек на основе из двухосной георешетки. Собранная конструкция засыпается гравелистым дренирующим минеральным материалом из изверженных пород с крупностью до 120 мм. Размеры берм приняты исходя из их способности обеспечить пригрузочное давление, способное противостоять выпору грунтов слабого основания (Берестяный и др., 2011).

Наиболее приемлемый вариант защиты железнодорожного пути от оползневых деформаций - строительство обхода по аллювиальным отложениям в долине р. Раздольная. При этом решается проблема спрямления плана железнодорожного пути.

При подобного рода работах необходимо учитывать сейсмотектоническую опасность регионального Нижне-Суйфунского разлома, совпадающего с долиной р. Раздольная, и современные вертикальные движения земной коры в этой зоне. Например, к центральной части НижнеСуйфунского разлома было приурочено землетрясение силой более 7 баллов, произошедшее 14 сентября 1955 г. в 15 ч по местному времени, в районе ст. Приморская, с эпицентром в пос. Кедровая Падь. Оно ощущалось в г. Владивосток и на ст. Океанская с силой 3 балла, чувствовалось до оз. Хасан в юго-западном направлении, до Уссурийска - в северо-восточном. Сейсмический толчок, продолжавшийся несколько секунд и сопровождавшийся гулом на поверхности земли, образовал трещины, поднял пыль, в горах вызвал обвалы. От берега отделилась волна, которая достигла Токаревского маяка (п-ов Эгершельд, г. Владивосток). Сотрясение было замечено даже машинистом во время движения паровоза (Лосив, 2015 ).

В пос. Приморский были повреждены все строения, в том числе и деревянные постройки, во многих зданиях были разрушены печи, упали дымовые трубы. Изосейсты этого землетрясения вытянуты в северо-восточном направлении на расстояние 200 км и резко сужены (до 25 км) вкрест простирания основных геологических структур. Магнитуда землетрясения составляет 4.4, глубина очага - 6 км (Уломов, 2009).

Близость эпицентра землетрясения к зоне Нижне-Суйфунского разлома и совпадение направления длинной оси эллипсов изосейст с его простиранием говорит о том, что землетрясение было связано с разрядкой тектонических 
напряжений в зоне этого разлома и что его активность может не ограничиваться участком в районе пос. Кедровая Падь, а распространится как к северо-востоку - до г. Уссурийск, так и к юго-западу - до бухты Бойсмана, т. е. о сейсмотектонической опасности всей северной половины трасс, проложенных вдоль зоны этого разлома.

Землетрясение в районе ст. Приморская показало современную тектоническую активность района. Этот фактор оказывает существенное влияние на интенсивность гравитационных процессов в районе.

\section{ЗАКЛЮЧЕНИЕ}

Проведенные исследования изучения оползневой опасности на Шуфанском плато для линейных объектов инфраструктуры позволили сделать следующие основные выводы:

1. Территория исследований имеет развитую транспортную и селитебную инфраструктуру, испытывает значительную техногенную нагрузку.

2. Геологическое строение территории специфично. В верхней части разреза участвуют элювиально-делювиальные образования четвертичного возраста, представленные желтобурыми глинами с хаотическим нагромождением щебня, дресвы, валунов и глыб базальтов 0.35.0 м в поперечнике. Они интенсивно меняют свои физико-механические свойства при увлажнении в условиях характерного приморского климата.

3. Климат района имеет определяющее значение в интенсивности опасных экзогенных процессов. Важной особенностью второй половины лета являются тайфуны. Обильное выпадение осадков, высокие относительная влажность и температура воздуха характерны для этого периода.

4. Указанные выше условия предопределяют активизацию неблагоприятных экзогенных процессов - оползней (являющихся ведущими в районе), карстовых процессов, оврагообразования и др., что затрудняет строительство и эксплуатацию транспортных магистралей и иные виды освоения территории.

5. На местности наблюдаются признаки оползневых процессов: деформации земляного полотна автомобильного шоссе и железнодорожной насыпи, наклоны телеграфных столбов, отсутствие водоотводной канавы с верховой стороны насыпи вследствие наступления языка оползня и др.

6. Анализ вариантов инженерной защиты от оползней по периферии Шуфанского плато показал, что их проектирование следует осу- ществлять со скрупулезным учетом особенностей инженерно-геологических условий. Наиболее рационально в данных инженерногеологических условиях применение комбинированных решений из геосинтетических интегральных георешеток разной конфигурации и пригрузочных берм из грунта, различной ширины в зависимости от высоты насыпи (нагрузки на основание) и мощности слабых грунтов в основании.

7. Наиболее приемлемый вариант защиты железнодорожного пути от оползневых деформаций - строительство обхода по аллювиальным отложениям в долине р. Раздольная. При этом решается проблема спрямления плана железнодорожного пути.

\section{ЛИТЕРАТУРА}

Берестяный Ю. Б., Кудрявиеев С. А., Вальйева Т. Ю., Михайлин Р. Г., Федоренко Е. В. Результаты исследований конструкций усиления земляного полотна при использовании современных методов численного моделирования и эффективных геосинтетических материалов // Проблемы земляного полотна железных и автомобильных дорог в условиях Сибири : тр. II регион. науч.-практ. конф. / отв. ред. А. Л. Исаков. Новосибирск : Изд-во СГУПС, 2011. С. 72-75.

Бормотов B. A. Пространственно-временные и энергетические характеристики систем сейсмогенерирующих разломных зон земной коры и мантии области сочленения Тихоокеанского и ЦентральноАзиатского подвижных поясов // Взаимосвязь между тектоникой, сейсмичностью, магмообразованием и извержениями вулканов в вулканических дугах : материалы IV междунар. совещ. по субдукционным процессам в Японской, Курило-Камчатской и Алеутской островных дугах, Петропавловск-Камчатский, 2127 августа 2004 г. Петропавловск-Камчатский, 2004. C. 196-198.

Геология СССР. Т. 32. Приморский край. Ч. 2. Геологическое описание. Москва : Недра, 1974. 156 с.

Государственная геологическая карта Российской Федерации. K-(52),53 (Владивосток). Третье поколение. Дальневосточная серия. Карта четвертичных образований. Масштаб: 1:100 000 / ред. А. Ю. Опекунов, ВНИИОкеанология, Дальморгеология, Приморская ПСЭ, ФГБУ «ВСЕГЕИ», 2008.

Комплект карт общего сейсмического районирования территории Российской Федерации (ОСР-2015). Изменение № 1 к СП 14.13330.2014 «СНиП II-7-81* Строительство в сейсмических районах» / Минстрой России, 1 декабря 2015 г.

Короткий А. М., Коробов В. В., Скрыльник Г. П. Обвалы и оползни юга Российского Дальнего Востока // Геоморфология. 2009. № 2. С. 50-60. https://doi. org/10.15356/0435-4281-2009-2-50-59

Лосив В. И. Оценка сейсмичности Приморья и региональная тектоника // Инженерные изыскания. Москва : Геомаркетинг, 2015. № 14. С. 24-35.

Маций С. И., Деревенец Ф. Н. Взаимодействие оползневого грунта со сваями с учетом конфигурации удерживающего сооружения // Основания, фундамен- 
ты и механика грунтов. Москва : Стройиздат, 2007. № 2. C. $8-12$.

Олейников А. А., Н. А. Олейников. Геологические признаки сейсмичности и палеосейсмогеология Южного Приморья. Владивосток : Дальнаука, 2001. $185 \mathrm{c}$.

Органова Н. М. Особенности современных движений на территории приморского землетрясения 1955 года и сопредельных районов на юго-западе Приморья. Владивосток : Дальнаука, 1977. 96 с.
Рынков В. С. Закономерности распространения и развития современных геологических процессов и явлений в Приморском крае // Проблемы инженерной геологии в связи с рациональным использованием геологической среды : Материалы Всесоюзной конференции. Ленинград : [б. и.], 1976. С. 113-117.

Уломов $B$. К оценке сейсмической опасности территории Приморского края // Инженерные изыскания. Москва : Геомаркетинг, 2009. № 1. С. 40-46.

Поступила в редакицию 27.05.2019 2.

Поступила после доработки 03.12.2020 2.

\title{
LANDSLIDE HAZARD FOR LINEAR INFRASTRUCTURE ON THE SHUFAN PLATEAU (Primorsky Krai)
}

\author{
S. V. Kvashuk', D. Yu. Maleev ${ }^{1}$, E. V. Fedorenko ${ }^{2}$ \\ ${ }^{1}$ Far Eastern State Transport University, Khabarovsk \\ ${ }^{2}$ Miakom SPb LLC, Saint-Petersburg
}

\begin{abstract}
Active visco-elastic mudslide streams are widely developed along the edges of basaltic flow formations on the Shufan Plateau. Brief orographic, tectonic, and geologic assessment of the area is given. Landslides, revinement, denudation violate the normal transportation rhythm. The results of studying the process conditions and causes are discussed. It is established that the main cause of mudflows is traffic arteries tracing along the low-grade (12-15 degrees) slopes built by unconsolidated clays, with of the clays transformation into plastic state during long drizzles, common in the area, as the principal one. Working out options or engineering protection of railroads against the mudflows at the outskirts of Shufan Plateau has shown that each is highly problematic. Seismotectonic hazard of the regional Lower-Suyfun fault, coinciding with the Razdolnaya River valleyas well as modern vertical movements of the earth crust in the area discussed have to be taken into account while exploring the territory.
\end{abstract}

\section{Keywords: Shufanskoye Plateau, site geology, seismic hazard, landslides, indicators, engineering protection.}

\section{REFERENCES}

Berestyany, Yu. B., Kudryavtsev, S. A., Valtseva, T. Yu., Mikhailin, R. G., Fedorenko, E. V., 2011. Results of the Investigations of Earthwork Structures Enforcement by Modern Methods of Numerical Modelling and Effective Geosynthetic Materials, Problems of Railroads and Highways in Siberia, Proceedings of the 2nd Regional Research Conference, Ed. A. L. Isakov. Novosibirsk, SPSTU, 72-75 [In Russian].

Bormotov, V. A., 2004. Time-Space and Energetic Characteristics of Earthquake-Generating Fault System Zones of the Earth Crust and the Mantle of the Pacific and Central-Asian Belts Junction, Interaction among Tectonics, Seismicity, Magma Formation, and Volcano Eruptions in Volcanic Arcs: Materials of the $4^{\text {th }}$ International Meeting on Subduction Processes in the Japanese, KurilKamchatkan, and Aleutian Island Arcs, PetropavlovskKamchatsky, August 21-27, 2004. Petropavlovsk-Kamchatsky, 196-198 [In Russian].

Federal Geologic Map of the Russian Federation. K(52),53 (Vladivostok). Third Generation. Far Eastern Se- ries. Map of Quaternary Formations. Scale 1: 100000. Ed. A. Yu. Opekunov, 2008. VNIIOkeonologiya, Dalmorgeologiya, Primorye PSE, VSEGEI [In Russian].

Geology of the USSR, 1974. Vol. 32. Primorsky Krai. Part 2. Geological Description. Moscow, Nedra [In Russian].

Korotky, A. M., Korobov, V. V., Skryl'nik, G. P., 2009. Rockfalls and Landslides in the South of Russia's Far East, Geomorfologiya.2, 50-60. https://doi.org/10.15356/04354281-2009-2-50-59 [In Russian].

Losiv, V. I. 2015. Estimation of Primorye Seismicity and Regional Tectonics, Engineering Survey, Moscow, Geomarketing Publishing. 14, 24-35 [In Russian].

Matsiy, S. I., Derevenets, F. N., 2007. Interaction of Sliding Soil with Piles, Considering the Retaining Structure Configuration, Soil Mechanics and Foundation Engineering. Moscow, Stroyizdat. 2, 8-12 [In Russian].

Oleynikov, A. A., Oleynikov, N. A., 2001. Geological Signs of Seismicity and Paleoseismology of Southern Primorye. Vladivostok, Dalnauka [In Russian]. 
Organova, N. M., 1977. Features of the Modern Motions in the 1955 Primorye Earthquake Area and Neighboring Territories of the South-Eastern Primorye. Vladivostok, Dalnauka [In Russian].

Rynkov, V. S., 1976. Regularities in the Spread and Development of Modern Geological Processes and Phenomena in Primorsky Krai, Problems of Engineering Geology in Connection with the Sustainable Use of the
Geological Environment, Proceedings of the All-Union Conference. Leningrad, 113-117 [In Russian].

Set of the Russian Federation Seismic Zoning Maps (OSR-2015), 2015. Change 1 to SP 14.13330.2014 "SNiP II-7-81* Construction in Seismic Regions" Minstroy Rossii, December 1, 2015.

Ulomov, V. I., 2009. On the Seismic Hazard Assessment for the Primorsky Krai Territory. Moscow, Engineering Survey. 1, 40-46 [In Russian]. 